\title{
Problems Faced by Camel Leather Artisans in Rajasthan
}

\author{
Swati Acharya* and Sudha Babel \\ Department of Textiles and Apparel Designing, CCAS, MPUAT, Udaipur, \\ Rajasthan-313001, India \\ *Corresponding author
}

\begin{abstract}
A B S T R A C T
\section{Keywords}

Heritage, Artisans, Leather,

Orthopaedic,

Scabies, Inherited

Article Info

Accepted:

20 May 2019

Available Online:

10 June 2019

Rajasthan has a rich cultural heritage and prolonged tradition of leather craft. Camel leather artisans play a vital rolein the cultural heritage i.e. something which is inherited from one's ancestors. The study took place in major district of Rajasthan on the basis of concentration of camel leather artisans in Bikaner, Barmer, Jaisalmer and Jodhpur. From each districts three areas were selected purposively which were dominated by camel leather workers. The sample of respondents constituted of sixty taking, fifteen from each of the four identified districts, including those who were involved in camel leather work directly or indirectly. Data revealed that cent per cent of the respondents reported that high cost of raw material, time constraint and finance were the major problems faced by camel leather artisans. Health is the main concern of the researcher and found that cent percent of the respondents suffers from various health issues i.e. orthopaedic disorders, blurred vision, body itching, sleep problems, breathing problems, scabies a skin condition caused by a burrowing mite and hand pain in varying frequencies. It is concluded that proper incentives, trainings and facilities should be provided for mitigating the problems of artisans.
\end{abstract}

\section{Introduction}

Rajasthan is a state of glorious history, ethnic traditions, vibrant culture and rich heritage. Also known as "Land of Maharajas" or "Land of Kings". Fairs and festivals are a reflection of diverse social and cultural heritage of the state. Since very long time it's being one of the major producer and supplier of handicraft products.

Handicraft depicts our community and culture. The livelihood of large number of population directly and indirectly depends on it. It plays a significant role for economic growth and upliftment of the rural economy through generation of employment and foreign exchange earnings. Further there is need to understand the growth and decline of craft, not only from economic perspective but from a broader livelihood perspective. In order for the optimum study of this handmade industry, government should take steps to provide both incentives and assistance. Along with this, state and central government must increase the wages and improve the working conditions of the artisans, who are involved in these industries (Mohi-ud-din et al., 2014). 
Over the years enormous pressure has been faced by the Indian handicraft sectors due to the arrival of new merchandized articles as a substitute for the traditional crafts and incur the risk on Indian handicraft products. Manifold obstacles are faced by the handicraft industry i.e. right from the procurement of the raw material due to non - availability of required standard input, unavailability of skilled artisans, unawareness about the technical supports and lack of customer awareness towards the craft products. Information dissemination is one of key issues faced by this sector (Kumar, 2014).

The present paper highlights the problems faced by the camel leather artisans in Rajasthan. It is the outcome of one aspect of the study undertaken to document the different problems faced, job satisfaction, health hazards along with exploration of the changing trends in this work since last four decades.

\section{Materials and Methods}

The present study was conducted to identify the problems faced by camel leather artisans. Sample of total sixty respondents were selected randomly from four districts of Rajasthan namely Bikaner, Barmer, Jaisalmer and Jodhpur, which were selected purposively on the basis of concentration of camel leather artisansin the region. Respondents were involved in camel leather work directly or indirectly, which included whole sellers, retailers, exporters and some tangled in doing all the work together from processing, manufacturing to sales at their own. It was based on a descriptive cum exploratory research design and includes both qualitative and quantitative data. For the purpose of collecting desired data from the respondents a structured interview schedule was developed by the researcher after comprehensive review of the available literature.
The questionnaire dealt with a section of open-end meant to elicit information regarding the general information, inventory, problems faced, related health hazards and change in trend. The artisans were interviewed individually at their own place and local language was used where needed. The purpose of the study was made clear to the respondents to gather clear and correct information. The collected data obtain from the survey was coded, tabulated and expressed in frequency and percentage in accordance with the study to arrive at meaningful and relevant interferences.

\section{Results and Discussions}

\section{Demographic information of the respondents}

Table 1 depict the general information of the respondents. It reveals that about one half of the respondents $(50 \%)$ were illiterate, more than one fifth $(21.66 \%)$ had education up to middle school and only 3.33 per cent has attained the education up to college level and above. It shows the lack of awareness about the education among the respondents (Fig. 1).

Caste involved in doing camel leather work were scheduled castes i.e. 45 per cent and 30 per cent respondents belonged to Jingar and Regar community respectively.

Data indicated that maximum number of respondents $(43.33 \%)$ had monthly income between Rs 1,500-5,000 and 16.67 per cent of the respondents fall between Rs 10,00015,000 and very few (13.33\%) were above Rs 15,000 per month.

The data shows that majority of the respondents $(53.33 \%)$ works from childhood (6-10 years) as follows 25 per cent respondents started work from adolescent (1420 years) and remaining 21.67 per cent of 
respondents were in teenage (10-14 years). Data revealed that 58.33 per cent of the respondents considered camel leather work as their main occupation. However 4.1 per cent were involved in some other occupations. During data collection researcher found that due to low earning of artisan's, the family members were found to be engaged in some other occupations.

\section{Problems faced by artisans}

Table 2 discloses the problems faced by camel leather artisans. One of the major problem faced were lack of interest/disinterest of the consumers towards the manually made products as they were fascinated towards the machine made finished goods which imparts the production with a better visual appearance as compared to those which are made manually.

It is clear from the table that due to nonavailability of raw camel hides artisans in all the selected area of study are facing scarcity of raw material.

The major problem reported by cent per cent of the respondents was high cost of raw material, time constraint as the respondents still uses traditional tools and old manufacturing methods.

Investigation encloses that rural youth were disinterested in continuing the family craft traditions due to two reasons: - Firstly, seined their parents struggling for markets and fair prices for the products. Secondly, todays school system does not integrate lessons regarding the importance of craft in curriculum and instead push the students towards other reputed jobs. The findings of the study were in consonance with Anonymous (2011) who reported that youngsters were no longer interested in pursuing career and does not want to associate themselves with the craft no longer as the work is still looked down upon in the society.

One of the crucial problems faced by camel leather artisans was the finance issue. Cent per cent of respondents faced problem of indebtedness. Efforts need to be made for providing credit and finance to the weaker artisans.

Ghouse (2012) listed various problems of artisans as follows: low/no demand, lack of access and high cost of raw materials, obsolete tools \& equipment, licensing problems and high cost of credit, labour regulations and policy uncertainty, poor infrastructure and scarcity of skilled labour, shipping problems, low subsidy, income tax and market awareness.

\section{Attributes responsible for changing trends}

Various attributes responsible for changing trend in camel leather products they were: Change in technology, mass media, marketing demand and pattern.

Data in table 3 portrays that in all four selected districts. Cent per cent of the respondents reported that print media, fashion trend and market demand are major attributes responsible for changing trend in camel leather products.

Changes in technology was another attribute in bringing change in current trend as reported 33.33 per cent respondents in Bikaner and Barmer followed by 46.67 per cent respondents in Jaisalmer. In Jodhpur 66.67 per cent of the respondents were affected by change in technology. With regard to marketing pattern 40 per cent respondents in Bikaner, 60 per cent respondents in Barmer, 66.67 per cent respondents in Jaisalmer and in Jodhpur 73.33 per cent respondents were found to be affected. 
Table.1 Distribution of respondents by demographic information

\begin{tabular}{|c|c|c|c|c|c|c|c|c|c|c|c|}
\hline \multirow{3}{*}{ Aspects } & \multirow{3}{*}{ Category } & \multicolumn{8}{|c|}{ Respondents } & \multicolumn{2}{|c|}{$\mathrm{n}=60$} \\
\hline & & \multicolumn{2}{|c|}{ Bikaner } & \multicolumn{2}{|c|}{ Barmer } & \multicolumn{2}{|c|}{ Jaisalmer } & \multicolumn{2}{|c|}{ Jodhpur } & \multicolumn{2}{|c|}{ Total } \\
\hline & & $\mathbf{F}$ & $\%$ & F & $\%$ & $\mathbf{F}$ & $\%$ & F & $\%$ & $\mathbf{F}$ & $\%$ \\
\hline \multirow{6}{*}{ Education } & Illiterate & 7 & 46.66 & 10 & 66.67 & 6 & 40 & 7 & 46.66 & 30 & 50 \\
\hline & $\begin{array}{l}\text { Can read and } \\
\text { write }\end{array}$ & 0 & 0 & 0 & 0 & 0 & 0 & 0 & 0 & 0 & 0 \\
\hline & $\begin{array}{l}\text { Up to primary } \\
\text { school }\end{array}$ & 2 & 13.33 & 4 & 26.67 & 2 & 13.33 & 4 & 26.66 & 12 & 20 \\
\hline & $\begin{array}{l}\text { Up to middle } \\
\text { school }\end{array}$ & 3 & 20 & 0 & 0 & 6 & 40 & 4 & 26.66 & 13 & 21.66 \\
\hline & $\begin{array}{l}\text { Up to high } \\
\text { school }\end{array}$ & 2 & 13.33 & 0 & 0 & 1 & 6.66 & 0 & 0 & 3 & 5 \\
\hline & $\begin{array}{l}\text { Graduate and } \\
\text { above }\end{array}$ & 1 & 6.66 & 1 & 6.66 & 0 & 0 & 0 & 0 & 2 & 3.33 \\
\hline \multirow{5}{*}{ Caste } & Muslim & 6 & 40 & 0 & 0 & 0 & 0 & 0 & 0 & 6 & 10 \\
\hline & Regar & 9 & 60 & 9 & 60 & 0 & 0 & 0 & 0 & 18 & 30 \\
\hline & Jingar & 0 & 0 & 6 & 40 & 11 & 73.33 & 10 & 66.66 & 27 & 45 \\
\hline & Khatri & 0 & 0 & 0 & 0 & 4 & 26.66 & 0 & 0 & 4 & 6.66 \\
\hline & Gujar & 0 & 0 & 0 & 0 & 0 & 0 & 5 & 33.33 & 5 & 8.33 \\
\hline \multirow{4}{*}{$\begin{array}{c}\text { Monthly } \\
\text { income } \\
\text { (Rs.) }\end{array}$} & $15,00-5,000$ & 5 & 33.33 & 7 & 46.66 & 6 & 40 & 8 & 53.33 & 26 & 43.33 \\
\hline & $5,000-10,000$ & 3 & 20 & 4 & 26.66 & 5 & 33.33 & 4 & 26.66 & 16 & 26.67 \\
\hline & $10,000-15,000$ & 2 & 13.33 & 2 & 13.33 & 3 & 20 & 3 & 20 & 10 & 16.67 \\
\hline & Above 15,000 & 5 & 33.33 & 2 & 13.33 & 1 & 6.66 & 0 & 0 & 8 & 13.33 \\
\hline \multirow{3}{*}{ Age Level } & $\begin{array}{l}\text { Childhood } \\
\text { (6-10 yrs.) }\end{array}$ & 7 & 46.67 & 8 & 53.33 & 7 & 46.67 & 10 & 66.67 & 32 & 53.33 \\
\hline & $\begin{array}{l}\text { Teenage } \\
\text { (10-14 yrs.) }\end{array}$ & 2 & 13.33 & 4 & 26.67 & 3 & 20 & 4 & 26.67 & 13 & 21.67 \\
\hline & $\begin{array}{l}\text { Adolescent } \\
\text { (14-20 yrs.) }\end{array}$ & 6 & 40 & 3 & 20 & 5 & 33.33 & 1 & 6.67 & 15 & 25 \\
\hline \multirow{2}{*}{$\begin{array}{c}\text { Family } \\
\text { Occupation }\end{array}$} & $\begin{array}{l}\text { Primary (Camel } \\
\text { leather work) }\end{array}$ & 8 & 53.33 & 9 & 60 & 10 & 66.67 & 8 & 53.33 & 35 & 58.33 \\
\hline & $\begin{array}{c}\text { Secondary } \\
\text { (other activities) }\end{array}$ & 7 & 46.67 & 6 & 40 & 5 & 33.33 & 7 & 46.67 & 25 & 41.67 \\
\hline
\end{tabular}


Table.2 Distribution of respondents by problem faced

\begin{tabular}{|c|c|c|c|c|c|c|c|c|}
\hline \multirow[t]{3}{*}{ Category } & \multicolumn{8}{|c|}{ Respondents } \\
\hline & \multicolumn{2}{|c|}{ Bikaner } & \multicolumn{2}{|c|}{ Barmer } & \multicolumn{2}{|c|}{ Jaisalmer } & \multicolumn{2}{|c|}{ Jodhpur } \\
\hline & $\mathbf{F}^{*}$ & $\%$ & $\mathbf{F}^{*}$ & $\%$ & $\mathbf{F}^{*}$ & $\%$ & $\mathbf{F}^{*}$ & $\%$ \\
\hline Lack of market & 10 & 66.67 & 8 & 53.33 & 0 & 0 & 0 & 0 \\
\hline $\begin{array}{l}\text { Raw material } \\
\text { supply }\end{array}$ & 8 & 53.33 & 9 & 60 & 10 & 66.67 & 11 & 73.33 \\
\hline $\begin{array}{l}\text { High cost of } \\
\text { raw material }\end{array}$ & 15 & 100 & 15 & 100 & 15 & 100 & 15 & 100 \\
\hline $\begin{array}{c}\text { Time } \\
\text { constraint }\end{array}$ & 15 & 100 & 15 & 100 & 15 & 100 & 15 & 100 \\
\hline $\begin{array}{c}\text { Lack of } \\
\text { interest among } \\
\text { family } \\
\text { members }\end{array}$ & 11 & 73.33 & 7 & 46.67 & 6 & 40 & 10 & 66.67 \\
\hline Finance & 15 & 100 & 15 & 100 & 15 & 100 & 15 & 100 \\
\hline
\end{tabular}

Table.3 Distribution of respondents by attributes responsible for changing trends

\begin{tabular}{|c|c|c|c|c|c|c|c|c|}
\hline \multirow[t]{3}{*}{ Aspect } & \multicolumn{8}{|c|}{ Respondents } \\
\hline & \multicolumn{2}{|c|}{ Bikaner } & \multicolumn{2}{|c|}{ Barmer } & \multicolumn{2}{|c|}{ Jaisalmer } & \multicolumn{2}{|c|}{ Jodhpur } \\
\hline & $\mathbf{F}^{*}$ & $\%$ & $\mathbf{F}^{*}$ & $\%$ & $\mathbf{F}^{*}$ & $\%$ & $\mathbf{F}^{*}$ & $\%$ \\
\hline $\begin{array}{l}\text { Change in } \\
\text { technology }\end{array}$ & 5 & 33.33 & 5 & 33.33 & 7 & 46.67 & 10 & 66.67 \\
\hline \multicolumn{9}{|c|}{ MASS MEDIA } \\
\hline Print media & 15 & 100 & 15 & 100 & 15 & 100 & 15 & 100 \\
\hline $\begin{array}{l}\text { Electronic } \\
\text { media }\end{array}$ & 6 & 40 & 10 & 66.67 & 12 & 80 & 15 & 100 \\
\hline Fashion trend & 15 & 100 & 15 & 100 & 15 & 100 & 15 & 100 \\
\hline $\begin{array}{l}\text { Market } \\
\text { demand }\end{array}$ & 15 & 100 & 15 & 100 & 15 & 100 & 15 & 100 \\
\hline $\begin{array}{c}\text { Marketing } \\
\text { pattern }\end{array}$ & 6 & 40 & 9 & 60 & 10 & 66.67 & 11 & 73.33 \\
\hline
\end{tabular}


Fig.1 Graphic illustration of the General information of respondents
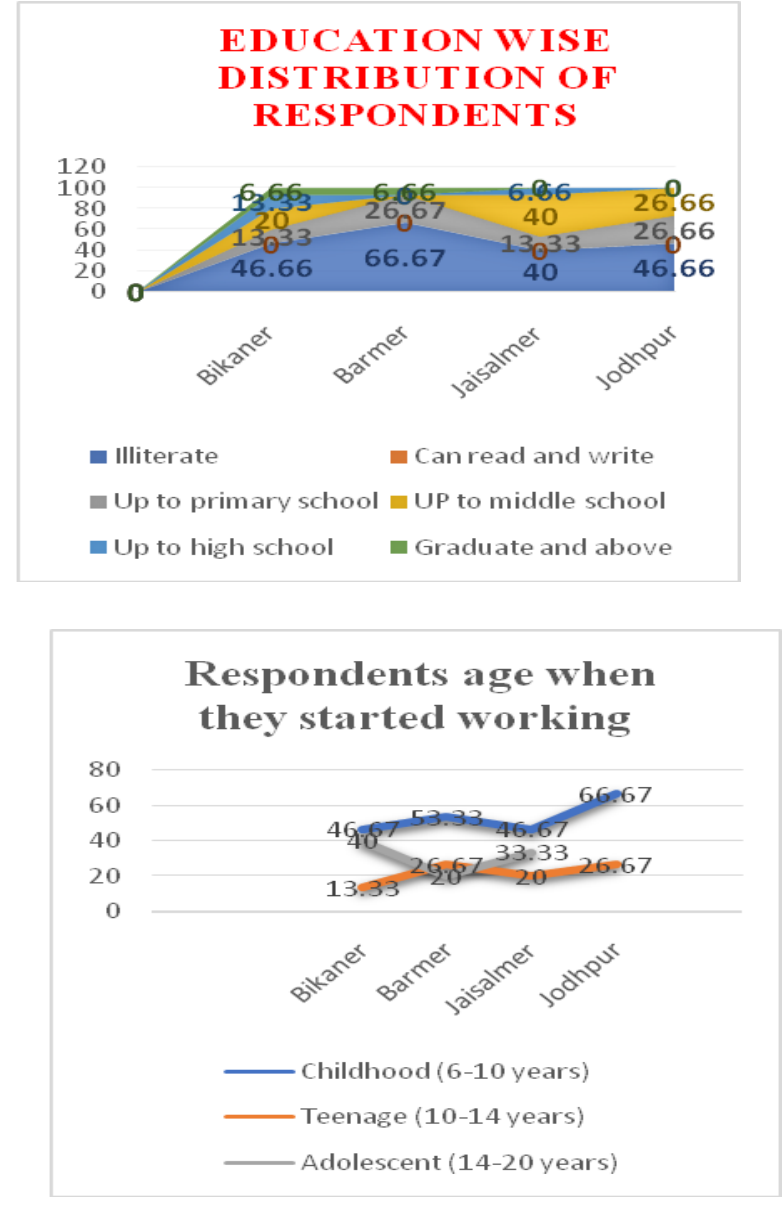

\section{Problems in storage of product}

Cent per cent of the respondents face problem in storage of leather goods, when the products are kept at the store for marketing purpose were exposed to direct, intense sunlight which triggers dark colouration of leather (from brown to dark brown) during the course of rainy season with high humidity in air the storage of goods become more difficult as a risk of mould formation. More importantly there is also a need to protect the goods from street dogs, pests, mice, rats and from leather worms which particularly eats vegetable tanned leather.

\section{Health hazards}

Cent percent of the respondents suffers from various health issues due to continuous working
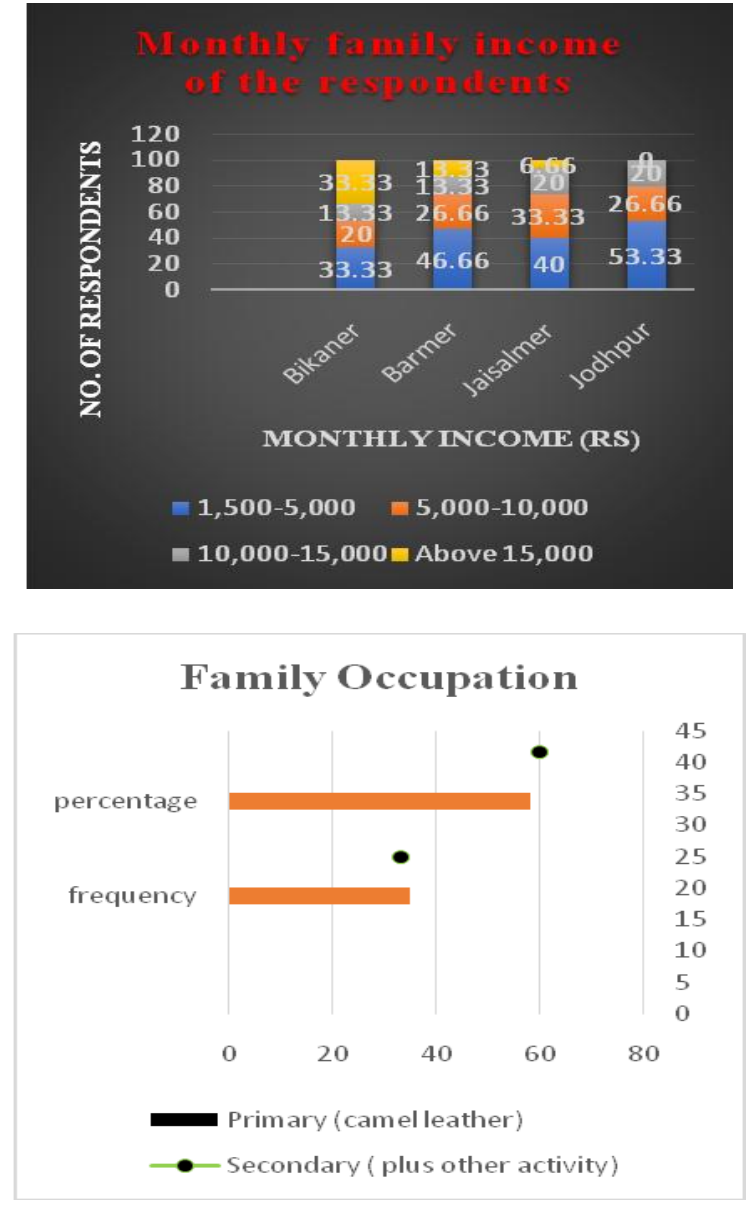

hours and improper postures. Artisans suffers from orthopaedic disorders i.e. back, knee, joint, foot, hand and leg pains and also suffer from blurred vision. It is because of cutting leather for making various utilitarian goods which require careful visionary angles.

Eye pain and itching, watery eyes, body itching, sleep problems, chest pain, cough, breathing problems, redness of eye, scabies a skin condition caused by a burrowing mite and hand pain were the other identified problems in varying frequencies.

"Artisans" the craftsmen which create unique, functional and decorative items with hands using traditional techniques. In the light of above result and discussion 'camel leather artisans' plays a vital role in the cultural 
heritage that is something which is inherited from once's ancestors.

It was observed that communities involved in craft belonged to scheduled castes i.e. Regar, Jingar, Khatri, Gujar and Muslim.

Obstacles related to lack of market, raw material supply, high cost of raw material, time constraints, lack of interest among family members and finances are the major problems that limit the growth of these artisans.

It has been found that artisans suffers from orthopaedic disorders, blurred vision, eye pain and itching, breathing problems, scabies and hand pain in varying frequencies.

Several factors that contribute to the unwillingness of artisans to pursue the business are low price of products, challenge to modify the products according to modern tastes, low remuneration, increased use if chrome tanned leather, buffalo leather, rexine in case of camel leather. Change in technology, mass media, fashion trend, marketing demand and pattern were the attributes responsible for changing trends of camel leather goods.

\section{References}

Ali, B., Yam, Z. and Khomeiri, M. 2015. Introduction to Camel origin, history, raising, characteristics, and wool, hair and skin: A Review. Research Journal of Agriculture and Environmental
Management. 4(11):506.

Anonymous, 2010. Indian Leather \& Tanning Industry Profile, Italian trade commission.

Retrieved

from http://italiaindia.com/images/uploads/pdf/ leather-industry-in-india-2010.pdf. on 22.01.19.

Anonymous, 2011. Impact of Tourism on Handicraft Industry. Retrieved from http://shodhganga.inflibnet.ac.in:8080/jsp ui/bitstream/10603/17652/11/11_chapter $\% 205$.pdf. on 24.04.19.

Ghouse, S. M. 2012. Indian handicraft industry: problems and strategies. International Journal of Management Research and Review. 2(7):1186.

Kumar, D. 2014. Marketing challenges of handicraft retailers in changing environment. International Journal of Business, Economics and Management. 4(10): 22-33.

Meera Sansthan. 2011. Development of Leather Cluster At Pratap Nagar \& Jodhpur City, Jodhpur. Retrieved from http://www.rajcluster.com/reports/cluster _2257.pdf. on 24.02.19.

Mohi-ud-din, T., Mir, L.A. and Bhushan, S. 2014. An Analysis of Current Scenario and Contribution of Handicrafts in Indian Economy. Journal of Economics and Sustainable Development. 5(9):78.

Nasr, A.I. 2015. Evaluation of Egyptian Camel Hides for Leathers Manufacturing. World Applied Sciences Journal. 33(8):13291333.

\section{How to cite this article:}

Swati Acharya and Sudha Babel. 2019. Problems Faced by Camel Leather Artisans in Rajasthan. Int.J.Curr.Microbiol.App.Sci. 8(06): 2527-2533. doi: https://doi.org/10.20546/ijcmas.2019.806.303 